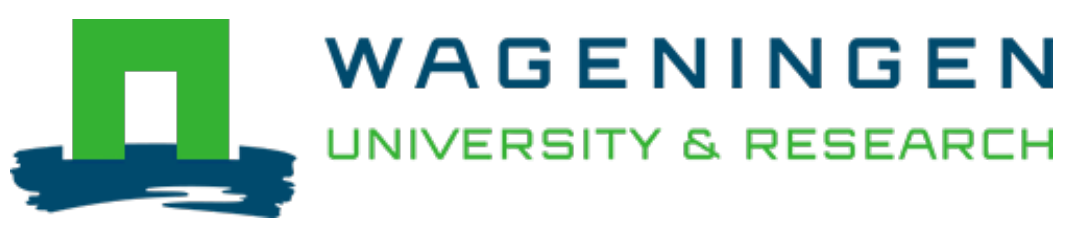

\title{
The effects of grinding, soaking and cooking on the degradation of amygdalin of bitter apricot seeds.
}

\author{
Food Chemistry \\ Tunçel, G.; Nout, M.J.R.; Brimer, L. \\ https://doi.org/10.1016/0308-8146(95)99841-m
}

This publication is made publicly available in the institutional repository of Wageningen University and Research, under the terms of article $25 \mathrm{fa}$ of the Dutch Copyright Act, also known as the Amendment Taverne. This has been done with explicit consent by the author.

Article 25 fa states that the author of a short scientific work funded either wholly or partially by Dutch public funds is entitled to make that work publicly available for no consideration following a reasonable period of time after the work was first published, provided that clear reference is made to the source of the first publication of the work.

This publication is distributed under The Association of Universities in the Netherlands (VSNU) 'Article $25 \mathrm{fa}$ implementation' project. In this project research outputs of researchers employed by Dutch Universities that comply with the legal requirements of Article $25 \mathrm{fa}$ of the Dutch Copyright Act are distributed online and free of cost or other barriers in institutional repositories. Research outputs are distributed six months after their first online publication in the original published version and with proper attribution to the source of the original publication.

You are permitted to download and use the publication for personal purposes. All rights remain with the author(s) and / or copyright owner(s) of this work. Any use of the publication or parts of it other than authorised under article $25 \mathrm{fa}$ of the Dutch Copyright act is prohibited. Wageningen University \& Research and the author(s) of this publication shall not be held responsible or liable for any damages resulting from your (re)use of this publication.

For questions regarding the public availability of this publication please contact openscience.library@wur.nl 


\title{
The effects of grinding, soaking and cooking on the degradation of amygdalin of bitter apricot seeds
}

\author{
G. Tuncel \\ Food Enginering Deportment, Ege Uhiversily, Bonowa. Lmir. Turkey \\ M. J. R. Nout \\ Deparment of Food Science, Agriculural Universily. Wageningen. The Netherlands \\ $\boldsymbol{\&}$ \\ L. Brimer \\ Department of Pharmacology and Palhobiulagy: Section of Pharmacology and Toxicology, Royal Velesintry and Agriculturat \\ Unjiversity. Frederiksberg, Denthark
}

(Received 13 October 1994; revised version received and accepted 13 December 1994)

\begin{abstract}
More than 650 metric tonnes of bitter apricot seeds are produced in Turkey per year as a by-product from the fruit canning industry. The seeds contain the toxic cyanogenic glycoside amygdalin in amounts up to ajound $150 \mu \mathrm{mol} / \mathrm{g}$ fresh weight. The effect of grinding, soaking and cooking on the degradation of amygdalin to prunasin, benzaldehyde cyanohydrin and $\mathrm{HCN}$, bas been studied, as has the release of these cyanides into the soaking water, Analysis for total cyanogcnic potential (TCP), cyanogenic glycosides and non-glycosidic cyanogens were thus made on a number of difierently processed seed batches. The parameters were: parlicle size, soaking time and temperature, the presence of a malural microflora, and the duration of cooking. Great reductions were obtained for all three values measured. i.e. from the initial TCP of $85 \mu \mathrm{mol} / \mathrm{g}$ and down to around $2-4 \mu \mathrm{mol} / \mathrm{g}$. However, none of the products oblained were considered safe for human consumplion. i.e. a further mierobiological deloxification must be added.
\end{abstract}

\section{INTKUDUCTION}

Apricot (Prunus armaniaca) is the most delicious stone fruil consumed during the summer season in Turkey. It is used fresh, or processed as apricot juice, nectar, jam or dried fruit. The amount of apricot seeds remaining after processing is quite large. Thus, over 600 metric tornes of bitter apricot seeds were exported by Turkey during 1992-1993 season (Eagen Export Association. pers. comm.). These are mainly used in the cosmetic industry with a minor fraction going to the food and condiments industry for the production of, for example, marzipan. However, depending on origin (variety, growth conditions, etc.) bitter apricot seeds contain approximately $50-150 \mathrm{mmol}$ per gram of dry weight of the toxic cyanogenic glycoside amygdalin, accompanied by minor amounts of prunasin (Abd E]-Aal et al., 1986; Tunçel et al. 1990). This character puts constraints to thejr wider use for human or animal nutrition, i.e. they require adequate detoxification. Thus cyanogenic glycosides and their products of hydrolysis (Fig. 1) may give rise to both acute intoxications and to chronic human CNS syndromes such as Konzo (Tylleskaer ef al, 1992).

Recent investigations by the authors showed that the detoxification resulting from processing involving a tempe fermentation (Rhizopus oligosporus) enabled a removal of around $70 \%$ of total cyanide potential. However, additional improvement of the detoxification process is required to obtain a completely safe product (Tuncel et al., 1990). The present paper describes the effects of grinding (particle size) and soaking (time and temperature) on the degradation of glycosides and release of cyanides into soaking watcr. In addition the effect of cooking $\left(100^{\circ} \mathrm{C}\right)$ on the removal of non-glycosidic cyanogens was evaluated. 


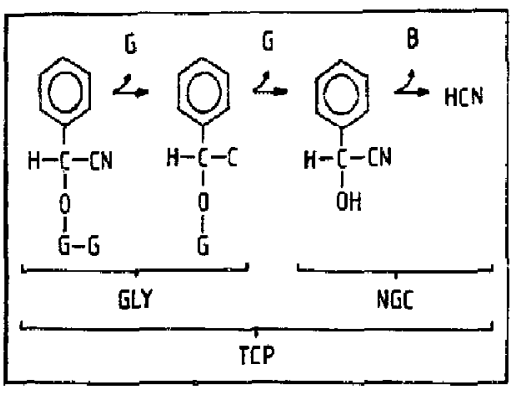

Fig. I. The enzymatic breakdown of amygdatin in apricots (Tunçel ot al. 1490). T(P. total cyanogens measured as 'total cyanogenic potential: GL $i$, glycosides: NGC. non-plycosidic cyanogens; G. glucose; B. benzaldehtde.

\section{MATERIALS AND METHODS}

\section{Materials}

Bitter upricot seeds were oblainud from Izmir. Turkey D-Amygdalin (A 6005) and pectinase (EC 3.2.1.15) from Rhisupus sp. (P 2401) - a source of hydrolytic enzymes for degradation of atnygdalin standards (Brimer \& Rosling. 1993) were purchased from Sigma (St. Louis. MO. USA). All other chemicals were of p.a. quality from Merck (Darmstadt. Germany). Picratc reugent sheets for the detection of reieased cyanide were prepared aceording to Brimer el al. (198.3) from pre-coated ion-exchange sheets (Polygram ionex 25-SB-Ac. Machery-Nagel. Duren. Germanyl. Shects were cut to size (dimensions of microtitre plate).

\section{Seed processing}

Apricot seeds were rinsed three simes with tap water and ground in a Simon mill (Henty Simon Lid. Stockport, UK). The particle size was determined using Karlb Kolb (Germany) test sieves and was grouped as follows: (a) coarse $4.5 \mathrm{~mm}$. (b) medium $2-3 \mathrm{~mm}$. (c) fine $<1 \mathrm{~mm}$ for the effect of particle stze. For the infitence of soaking time/lemperature. particle size 2-4 $\mathrm{mm}$ was used. Ground seeds were Ireated with different soaking and cooking conditions following the experimental design oullined below.

\section{The influence of particle size and souking time'}

Ground and sicved seeds were divided into subportions of $10 \mathrm{~g}$. Seeds were mixed with $30 \mathrm{ml}$ of water in beakers and incubated at approx. $30^{\circ} \mathrm{C}$. At each of the times (start $=0$ min. 30 min. $1 \mathrm{~h}, 3 \mathrm{~h} .6 \mathrm{~h}$ and $22 \mathrm{~h}$ ) two beakers were trealed as follows:

(a) the total content of the beaker was poured into a coned paperfilter (Whatman ashless 41 ), the outlet going into a measuring cylinder:

(b) the filtrate (volume noted) was poured into $90 \mathrm{ml}$ of $0.1 \mathrm{M}$ ortho-phosphoric acid; (c) the filter cake was poured into $90 \mathrm{ml}$ of orthophosphoric acid.

All such prepared samples and whole washed seeds were analysed for total cyannenic potential and for non-glycosidic cyanogens. as described below.

The influence of smaking sime/temperature, natural fora rand cowking

Portions of seeds $(10 \mathrm{~g})$ were soaked in $30 \mathrm{ml}$ of tap water with or withoul the addition of a preservative $(0.2 \% \mathrm{w} / \mathrm{v}$ of thymol), at (wo different controlled temperatures $(25$ and $35^{\circ} \mathrm{C}$ for 4 and $22 \mathrm{~h}$, respectively. to investigute the influence of the natural fora during soaking. To investigate the influence of cooking on the removal of non-glycosidic cyanogens. cooking was done after various times of soaking. Beakers were heated up on i hot plate is min) to boiling and placed in a open water bath at $100^{\circ} \mathrm{C}$ for 5.15 and $30 \mathrm{~min}$. Samples were then treated as outlined above. and analysed for cyanogens.

\section{Chemical analysis}

Lurartion of glycosides amd degrodation products

Simples Ifiltrites or filter cakes plus $90 \mathrm{ml}$ of $0.1 \mathrm{M}$ ar/ho-phosphoric actd) were homogenised in a glass blender jar (Bratun Mudtimix MX 32 type 4207. Braun. Germany as follows: $15 \mathrm{~s}$ speed $1.1 \mathrm{~min}$ speed $3.1 \mathrm{~min}$ rest. I min speed 3 (Cooke. 1978). This results in stable alcidic homogenales (designated $A$ ).

\section{Allahisis}

Jus1 prior to analysis. unstable working solutions (B) were prepared from $5 \mathrm{~mL}$ of the stable acidic homogernates (A). adding phosphate buffer (0-1 M Na $\mathrm{NO}_{\mathrm{s}} /$ $\mathrm{H}_{7} \mathrm{PO}_{4}$. $\mathrm{pH} 7$ to give $\mathrm{B}$ with at resulting $\mathrm{pH}$ of 6.5 (dilution factor was noted). Analysis was done using solid stitc detection of relcased HCN (Brimer \& Molgatard. 1986\%, measurements for total cyanogenic potentiul and non-glycosidic cyanogens, respectively, being performed as dexcribed by Brimer (1994). Standard graphs were produced by hydrolysis of aliquoles of a $1 \mathrm{mM}$ aqueous solution of amygdalin. a $0.2 \%$ w/v solution of pectinase being used as source of hydrolytic enzymes for both standards and samples to be analysed for total cyanogenic potential (Brimer \& Rosling. 1993). Sample hydrolysis was performed in microtitre plates (Brimer et 4l., 1993). using the following set-up (Nout er al, , 1995). In a microtitre plate. the following wells were prepared in duplicate: (a) anrgatalin standards: 10,20 and $30 \mu \mathrm{l}$ amygdalin $+100 \mu \mathrm{l}$ pectinase + distilled water totalling $200 \mu$; (b) total clunugenic potenriul (TCP = intact glycosides + degradation products): concentrated sample - $100 \mu \mathrm{l}(\mathrm{B})+100 \mu \mathrm{l}$ pectinase; diluted sample $-10 \mu \mathrm{I}$ (B) $+90 \mu$ d distilled water $+100 \mu l$ pectinase: (c) nonglycosidic cyanogens (NGC $=\mathrm{HCN}+$ cyanohydrins): concentrated sample - $[00 \mu l(B)+100 \mu]$ distilled water; diluted samplc $-10 \mu \mathrm{l}(\mathrm{B})+[10 \mu \mathrm{l}$ distilled water. Plates werc covered with picrate sheets and incubated at $25^{\circ} \mathrm{C}$ overnight. In this way, one microtitre plate 
accommodated a three-level amygdalin calibration and three difficrent samples (Nout et al. 1995).

\section{Assessment}

The density of the red-brown spols on yellow background typical of positive reactions. was assessed by measuring the absorption of transmitted light at $540 \mathrm{~nm}$ using a microtitre plate reader (Dynatech MR5000) (Brimer et a!., 1993; Brimer 1994). Using the amygdalin standards for calibration in each picrate sheet, extinctions of either dilute or concentrated sample which were closest to the standard, were used for calculations. Degradation products labelled as 'non-glycosidic cyanogens' were based upon well type (c). the difference of total cyanogenic potential (well type b) and degradation products being labelled as 'glycosides'. All were expressed as $\mu \mathrm{mol} / \mathrm{g}$ fresh weight of seeds processed, i.e. dry weight was not determined on the different soaked qualities. The detection level was $1 \mu \mathrm{mol} \mathrm{HCN} / \mathrm{g}$

\section{Determination of dry' u'eight}

Steds rinsed with lap water were weighed and dried to constant weight at $105^{\circ} \mathrm{C}$.

\section{RESULTS AND DISCUSSION}

The effect of particle size and soaking lime on the degradation of amygdalin and release of cyanides into soaking waler is shown in Table 1. The data show a similar trend as observed carlier (Tuncel et al. 1990). indicaling that endogenous B-glycosidase activity causes signiticant degradation of amygdalin during grinding and subsequent soaking. As expected, finer particles in general result in faster degradation of glycosides. Thus, finely ground seeds contained no glycosides after $0.5 \mathrm{~h}$ of soaking, while soaking of medium and coarsely ground seeds left 3-5 $\mu \mathrm{mol} / \mathrm{g}$ and 5-8 $\mu \mathrm{mol} / \mathrm{g}$ of amygdalin respectively after 6-22 h (Table 1). In soaking water no glycosides were found, while up to around $13 \mu \mathrm{mol} / \mathrm{ml}$ of non-glycosidic cyanogens were accumulated from finely ground seeds. Accumulation was found slightly lower for soaking waters of medium and coarsely ground seeds (Table 1).

In Table 2, the effect of soaking time versus temperature is presented. To investigate the influence of the natural flora during soaking, soaking was further done

Table 2. The effect of soaking time and tewapernture on the degradation of anygdalin $\left(\mu \mathrm{m}_{0} \mathrm{~V} / \mathrm{g}\right)$ in ground bitter apricot seed (2-4 anm particle size)

\begin{tabular}{lccc}
\hline \multirow{2}{*}{$\begin{array}{l}\text { Treatment, } \\
\text { soaking }\end{array}$} & \multicolumn{3}{c}{ Fresh weight basis $^{b}$} \\
\cline { 2 - 4 } & NGC & TCP & GLY \\
\hline $25^{\circ} \mathrm{C} / 4 \mathrm{~h}^{\circ}$ & 12.6 & 23.8 & 11.2 \\
$29^{\circ} \mathrm{C} / 4 \mathrm{~h}^{-}$ & 130 & 34.0 & 21.0 \\
$29^{\circ} \mathrm{C} / 22 \mathrm{~h}^{\circ}$ & 10.3 & 16.4 & 6.1 \\
$25^{\circ} \mathrm{C} / 22 \mathrm{~h}^{\circ}$ & 100 & 17.2 & 7.2 \\
$35^{\circ} \mathrm{C} / 4 \mathrm{~h}^{*}$ & 10.9 & 17.3 & 6.4 \\
$35^{\circ} \mathrm{C} / 4 \mathrm{~h}$ & 10.7 & 14.8 & 4.1 \\
$35^{\circ} \mathrm{C} / 22 \mathrm{~h}^{\circ}$ & 11.4 & 14.7 & 3.3 \\
$35^{\circ} \mathrm{C} / 22 \mathrm{~h}$ & 12.8 & 13.8 & 1.0 \\
\hline
\end{tabular}

"Concentrations in soaked seeds (= filtercakes) based on the fresh weight of the seeds processed: ${ }^{+}$soaked with addition of thymol: " soaked without thymol.

TCP. 1otal cyanogenic polential; GLY, glycosides (amygdalin + prunasin): and NGC, non-elycosidic cyanogens (cf. Fig. 1).

Table 1. The effect of particle size and soaking time on the degradation of amygdalin and release of cyanides into soaking water $(\mu \mathrm{mol} / \mathrm{g}$ FW)

\begin{tabular}{|c|c|c|c|c|c|}
\hline Seed treestment & $\mathrm{NGC}$ & TCP & GLY & $\begin{array}{l}\text { Soaking water } \\
\text { treatment }\end{array}$ & $\begin{array}{l}\text { NGC }^{\phi} \\
(=\mathrm{TCP})\end{array}$ \\
\hline Raw & $2.1(2-3)$ & $83.9(91.7)$ & $81.8(88.9)$ & & \\
\hline Ground fine & $23.5(27.0)$ & $38.1(43.8)$ & $146(168)$ & & \\
\hline Ground medium & $8.6(9.9)$ & $27.6(31.7)$ & $190(218)$ & & \\
\hline Graund cosrse & $7 \cdot R(9 \cdot 0)$ & $21 \cdot 3(24 \cdot 5)$ & $135(15.5)$ & & \\
\hline Soaked 0h fine & 10.6 & $19 \cdot 4$ & 8.8 & oh fine & 12.9 \\
\hline Snaked 0h medium & 8.9 & 16.5 & 7.6 & Oh medium & 6.2 \\
\hline Soaked 0h coarse & 7.2 & 23.1 & 159 & Oh coatse & 1.3 \\
\hline Soaked $0.5 \mathrm{~h}$ fine & $21 \cdot 3$ & $21 \cdot 3$ & - & $0.5 \mathrm{~h}$ fine & 11.1 \\
\hline Suaked I h fine & 15.6 & $15 \cdot 6$ & --. & I h finc & 12.6 \\
\hline Soaked I h medium & 10.9 & 15.1 & 4.2 & I h medium & 7.4 \\
\hline Soaked I h coarse & $10 \cdot 6$ & 18.1 & 7.5 & I h coarse & 9.7 \\
\hline Soaked 3h tine & 20.6 & $20 \cdot 6$ & - & $3 \mathrm{~h}$ fine & 133 \\
\hline Soaked $3 \mathrm{~h}$ medium & 13.5 & 23.9 & 10.4 & $3 \mathrm{~h}$ medium & 71 \\
\hline Soaked 3h coarse & 10.0 & 210 & 11.0 & $3 \mathrm{~h}$ coarse & 4.8 \\
\hline Soaked $6 \mathrm{~h}$ fine & 15.6 & 156 & -. & 6 h fine & 110 \\
\hline Soaked th medium & 14.6 & 18.1 & 3.5 & oh medium & 50 \\
\hline Soaked 6h coarse & 11.4 & 164 & 5.0 & $6 \mathrm{~h}$ coarse & 50 \\
\hline Soaked 22h fine & 14.7 & 14.7 & - & $22 \mathrm{~h}$ finc & 7.0 \\
\hline Soaked $22 \mathrm{~h}$ medium & II.9 & 16.3 & 44 & $22 \mathrm{~h}$ medium & 5.1 \\
\hline Soaked 22 h coarse & $7 \cdot 1$ & 15.7 & 8.6 & $22 \mathrm{~h}$ course & $4 \cdot 3$ \\
\hline
\end{tabular}

"Concentrations in soaked seeds ( $=$ filtercakes) based on the fresh weight of the seeds processed. figures in brackets $\mu$ mol/g DW. "No glycosides found in soaking waters.

- $[=$ below limit of detection $\}$.

TCP, tolal cyanogenic potential; GLY, glycosides (amygdalin + prunasin); and NGC, non-glycosidic cyanogens ( $f f$. Fig. l). 
with and without the addition of the preservative thymol. Results for $25^{\circ} \mathrm{C}$ correlate well with those presented in Table 1, the effect of the natural flora being insignificant at this temperature. The degradation of glycosides proved to be signiticantly $(P<0.01)$ more efficient at $35^{\circ} \mathrm{C}$, as seen already at $4 \mathrm{~h}$, an influence of the natural flora being indicated as a trend when looking at the time course of the hydrolysis. In agreement with the results from Table I, the total cyanogenic potential decreases very slowly under the conditions used, independent of particle size, temperature and the existence of a natural microllora. Thus. the non-glycosidic cyanogens tend to be quite stable under the aqueous conditions of natiral soaking, as also reported from studies on the breakdown of the cyanogenic glacoside linamarin in cassava (Mlingi et al. 1993). Removal of the accumulated non-glycosic cyanogens (cyanohydrins + HCN) might possibly be accomplished by filtering followed by drying of the seed cake. as results indicate from studies on cassava. In the preseni study we wanted to investigate the influence of open pan cooking in the soaking medium. As seen from the results in Table 3, a great reduction of non-glycosidic cyanogens is achieved after only 5 min of cooking. Complete removal seems to be difficult to achieve even with cooking times of $30 \mathrm{~min}$. however, in general. the glycosidic fraction is rather stable to even prolonged cooking (Table 3).

The results presented show, that both grinding and soaking cause a considerable reduction in the total cyanogenic potential. resulting in accumulation of non-

\begin{tabular}{|c|c|c|c|c|}
\hline \multirow[t]{2}{*}{ Sample } & \multirow{2}{*}{$\begin{array}{l}\text { Treatment } \\
\text { (min of } \\
\text { cooking) }\end{array}$} & \multicolumn{3}{|c|}{ Fresh weight husis ${ }^{h}$} \\
\hline & & $\mathrm{NGC}$ & TCP & GLY \\
\hline Soaked $25^{\circ} \mathrm{C} / 4 \mathrm{~h}^{*}$ & $\begin{array}{r}0 \\
5 \\
15 \\
30\end{array}$ & $\begin{array}{r}126 \\
49 \\
\cdots \\
\cdots\end{array}$ & $\begin{array}{r}23.8 \\
84 \\
20 \\
--\end{array}$ & $\begin{array}{r}11.2 \\
3.5 \\
20 \\
-\end{array}$ \\
\hline Soaked $25^{\circ} \mathrm{C} / 22 \mathrm{~h}^{*}$ & $\begin{array}{r}0 \\
5 \\
15 \\
30\end{array}$ & $\begin{array}{c}10.3 \\
2.7 \\
-\end{array}$ & $\begin{array}{r}16.4 \\
9.7 \\
7.2 \\
3.8\end{array}$ & $\begin{array}{l}6.1 \\
7.0 \\
6.5 \\
3.8\end{array}$ \\
\hline Soakcd $25^{\circ} \mathrm{C} / 22 \mathrm{~h}$ & $\begin{array}{r}0 \\
5 \\
15 \\
30\end{array}$ & $\begin{array}{r}10.0 \\
2.3 \\
1.0\end{array}$ & $\begin{array}{r}17.2 \\
11.8 \\
8.3 \\
6.5\end{array}$ & $\begin{array}{l}7.2 \\
9.5 \\
7 \cdot 3 \\
6.4\end{array}$ \\
\hline Soaked $35^{\circ} \mathrm{C} / 22 \mathrm{~h}^{\prime}$ & $\begin{array}{r}0 \\
5 \\
15 \\
30\end{array}$ & $\begin{array}{r}11.4 \\
3.9 \\
40 \\
3.0\end{array}$ & $\begin{array}{r}14.7 \\
7.3 \\
7.8 \\
6.6\end{array}$ & $\begin{array}{l}3.3 \\
3.4 \\
3.8 \\
3.6\end{array}$ \\
\hline Soaked $35^{\circ} \mathrm{C} / 22 \mathrm{~h}$ & $\begin{array}{r}0 \\
5 \\
15 \\
30\end{array}$ & $\begin{array}{r}13.0 \\
2.2 \\
1.0\end{array}$ & $\begin{array}{r}13 \cdot 8 \\
7.1 \\
7.1 \\
4.6\end{array}$ & $\begin{array}{l}0.8 \\
4.9 \\
6.1 \\
4.6\end{array}$ \\
\hline
\end{tabular}

"Concentrations in soaked seeds ( $=$ fillercakes) based on the fresh weight of the seeds protessed; ' soaked with addilion of thymol: soaked without thymol.

'TCP. total cyarogenic potential; GLY, glycosides (amygdalin + prunasin): and NGC, non-glycosidic cyanogens (cf. Fig. I).

'--. below limit of detection. glycosidic cyanogens in the wet seed material as well as in the soaking water. In spite of the great reductions, none of the wel seed producls reach levels of total cyanogenic potential as low as those set for cossava Hour (CAC, 1988) and gari from cassava (FAO. 1989), i.e. 10 and $2 \mathrm{mg} \mathrm{HCN} / \mathrm{kg}$ (equalling 0.4 and $0.07 \mathrm{mmol}$ HCN/kg), not even after cooking. For samples of medium and coarse particle size, remaining concentrations of glycosides (amygdalin + prunasin) are also well above these levels, pointing to the necessity of using microbiological processing in order to obtain acceptable food or feed products from a surplus of bitter apricot seeds.

\section{ACKNOWLEDGEMENTS}

The financial support by NATO Collaborative Research Grant 920109 is gratefully acknowledged. The authors thank Prol. D. Göktan, Food Engineering Department. Ege University, for his constructive criticism during this investigation.

\section{REFERENCES}

Abd E-Aal. M. H.. Hamza. M. A. \& Rahma, E. H. (1986) In vitro digestibility. physicochemical and functional propcrties of apricot kernel proteins. Food Chem., 19, 197-211.

Brimer. L. (1994). Quantitalive solid-state detection of cyanogens: from field test kjts to semi-automated laboratoraty systems allowing kinetic measurements. Acta Honicuft. 375, 105-16.

Brimar, L. \& Molgaard. P. (1986). Simple densitometric method for eslimation of cyanogentc glycosides and cyanohydrins under field conditions. Biochem. Syst. Ecol. $14,97-103$.

Brimer, L. \& Rosling. H. (1993), Microdiffusion method with solid state detcction of cyanogertic glycosides from ctssava in human urine. Foud Chem. Toxicol.. 31. 599-603.

Brimer, L., Brogger Christensen, S. Molgaard, P. \& Naney, F. (1983). Determination of cyanogenic compounds by thin layer chromatography. I. A densitometric method for quantification of cyanogenic glycosides, employing enzyme preparations ( $\beta$-elucuronidase) from Helix partatia and picrate-impregnated ion-exchange shests J. Agric, Food Chtm. 31. 789-93.

Brimer. L., Tunçal, G. \& Noul. M. J. R. (1993). Simple screening procedure for micro-organisms to degrade amygdalin. Bisfecimol. Trth, 7, 683-7.

CAC (Codex Alimentarius Commision) (1988). Report of the Eighth Session of the Codex Cuondinating Comminte for Africu. FAO/WHO Cairo. Egypt.

Cookc. R. D. (1978). An enzymatic assay for the total cyanide content of cassava (Manihus esculenta Crantz). J. Sci. Food Agric., 29, 345-52.

FAO (Food and Agriculture Organization) (1989). African regional standard for Gari. In Codex Alimentarius Abridged Version. FAO, Rome, Ilaly, pp. 17.1-17.2.

Mlingi, N. V., Assey, V. D., Swai, A. B. M+4 McLarty, D. G., Korlen, H. \& Rosling. H. (1993). Cyanide exposure from cassava consumplion in northern Tanzania. Int. J. Food Sri. Nulr. 44.137-44.

Nout, M. J. R.. Tuncel, G. \& Brimer, L. (1999). Microbial degradation of amygdalin of biuter apricot seeds (Prunus armenioca). Int. J. Food Micrabiol., 24, 407-12.

Tunçel, G., Nout, M. J. R., Brimer, L. \& Göktan, D. (1990). 
Toxicological, nutritional and microbiological evaluation of tempe fermentation with Rhizopus oligosporus of bilter and sweet apricot seeds. Imt. J. Food Microbiol, 11, 337-44.
Tylleskater, T., Banea, H.. Bikagi, N., Cooke, R. D., Poulter, N. H. Rosling, H. (1992). Cassava cyanogens and Konzo, an upper motoneuron disease found in Africa. Lances, 339, 208-11. 